\title{
Witchcraft Accusations in Nineteenth- and Twentieth-century Europe
}

\section{Owen Davies}

Over the last twenty years or so there has been a slow but growing recognition that there is a history of witchcraft accusations after the end of the witch trials. From the nineteenth century onwards there were many educated European voices claiming that the belief in witchcraft was a relic of the past, and that only the peasantry and uneducated people in remote and backward areas of the countryside feared witches. There was confidence that those forces of modernity such as the expansion of education, industrialisation, urbanisation, professional policing, mechanisation, the railways, and the telegraph would eventually enlighten the darkest corners where 'superstition' was thought to linger. But over and over again across Europe the press reported with shock and revulsion some new instance of brutality against suspected witches. Clergymen wrote and published admonishing sermons about the continued abuse of those accused of bewitching in their parishes. When the folklorists of the late-nineteenth and early-twentieth centuries went collecting examples of supposedly archaic beliefs and traditions they found that belief in the existence of witches was still widespread in rural communities. Jump half a century to the 1960s and 1970s and a series of studies by ethnographers and anthropologists revealed that witchcraft accusations were still being made in France and Germany. ${ }^{1}$ So despite two centuries of confidence that witcheraft belief was an historic stage in human progress the facts on the ground suggested otherwise.

Until fairly recently, historians did not view witchcraft accusations in modern Europe as a serious topic for study; continued manifestations of witchcraft belief were not considered significant or revealing. They were mentioned as curiosities and designated a matter for folklorists to study. In the 1980s and 1990s, however, inspired in part by the French and German ethnographic studies, some historians began to reflect more seriously on piecing together the history of witchcraft between the days of the trials and the contemporary

\footnotetext{
${ }^{1}$ Jeanne Favret-Saada, Les mots, la mort, les sorts (Paris, 1977), published in English as Deadly Words: Witchcraft in the Bocage, trans. Catherine Cullen (Cambridge, 1980); Inge Schöck, Hexenglaube in der Gegenwart: empirische Untersuchungen in Südwestdeutschland (Tübingen, 1978); Hans Sebald, Witchcraft: The Heritage of a Heresy (New York, 1978).
} 
evidence. ${ }^{2}$ Questions began to be asked regarding how widespread witchcraft belief had been over the previous two centuries. To what extent had it declined? How reliable was the evidence collected by the early folklorists? And how should their material be interpreted by historians? Who continued to accuse people of witchcraft? And who were the accused? To what extent did the nature and pattern of nineteenth and twentieth-century witchcraft mirror the findings of early-modern historians exploring the trial records? Did the European emigrants who went overseas in vast numbers continue to make witchcraft accusations in their new communities and environments? Today the history of European witchcraft in the modern era is well established yet historical studies are still relatively few. So we have some substantive work on England, Denmark, the Netherlands, Germany, Hungary, Finland, and France, but comparatively little historical research (as distinct from ethnographic work) to compare it to with regard to Spain, Scotland, Austria and Italy, for example. There is much more work to be done in all areas to better answer the questions posed above.

Historians of early-modern witchcraft accusations rely on criminal records and pamphlets that provide details of witch trials. Once witchcraft was expunged from the law

${ }^{2}$ See Gustav Henningsen, 'Witch Persecution after the Era of the Witch Trials', ARV 44 (1988), 103-53; Judith Devlin, The Superstition Mind: French Peasants and the Supernatural in the Nineteenth Century (New Haven, 1987); Willem de Blécourt, 'On the Continuation of Witchcraft', In Jonathan Barry, Marianne Hester, and Gareth Roberts (eds), Witchcraft in Early Modern Europe: Studies in Culture and Belief (Cambridge, 1996), pp. 335-352; Owen Davies, Witchcraft, Magic and Culture, 1736-1951 (Manchester, 1999); Marijke GijswijtHofstra, 'Witchcraft after the Witch-Trials', in Marijke Gijswijt-Hofstra, Brian P. Levack and Roy Porter, Witchcraft and Magic in Europe: The Eighteenth and Nineteenth Centuries (London, 1999), pp. 95-191; Willem de Blécourt, 'The Witch, Her Victim, The Unwitcher and the Researcher: The Continued Existence of Traditional Witchcraft', in Willem de Blécourt, Ronald Hutton and Jean La Fontaine, Witchcraft and Magic in Europe: The Twentieth Century (London, 1999), pp. 141-220; Owen Davies \& Willem de Blécourt (eds), Beyond the Witch Trials: Witchcraft and Magic in Enlightenment Europe (Manchester University Press, 2004); Willem de Blécourt \& Owen Davies (eds), Witchcraft Continued: Popular Magic in Modern Europe (Manchester University Press, 2004); Nils Freytag, Aberglauben im 19. Jahrhundert. Preußen und seine Rheinprovinz zwischen Tradition und Moderne (1815-1918) (Berlin, 2003); Laura Stark, The Magical Self: Body, Society and the Supernatural in Early Modern Rural Finland (Helsinki, 2006). 
books of Europe these sources dry up, of course. Yet, despite the decriminalisation of witchcraft, criminal records remain an important source of information about witchcraft accusations. There are slander prosecutions, for example. Slander cases concerning witchcraft accusations occasionally occurred during the witch trials and continued to occur sporadically in some parts of Europe into the twentieth century, in German-speaking areas in particular. In June 1891, for example, a Viennese waitress named Fanny Stroble brought a slander suit against a servant girl named Maria Wirzar. The latter had accused Stroble of being a 'cannibal, witch, and night hag' who visited her at night to suck her blood, leaving her weak and emaciated. The following year Elizabeth Hörrath, of Obermichelbach, Bavaria, was imprisoned for ten days for accusing her aunt and mother of being witches. She told neighbours she had seen her mother riding on the back of a cow and that it had subsequently stopped giving milk. ${ }^{3}$ During the late-nineteenth and early-twentieth centuries GermanAmerican immigrants also made good use of the American courts to counter witchcraft slander. $^{4}$

As we shall see shortly, people continued to take the law into their own hands with regard to dealing with witches, and this led to what have been called 'witch trials in reverse'. These occurred when those physically abused or harassed for being suspected witches prosecuted their tormentors. Murder and manslaughter trials also took place when accused witches died from the ill-treatment meted out by their accusers. Much information about witchcraft accusations in the period can also be gleaned from the prosecution of cunning-folk. These multi-faceted practitioners of folk magic offered a wide range of services, including fortune-telling, herbal medicine, love magic, treasure hunting, thief detection, astrology, and, most importantly, protection from witcheraft, and the identification and punishment of accused witches. During the witch-trial era the laws against witchcraft forbade the practices of cunning-folk. Good magic was considered as bad as, and even worse than, the maleficium of accused witches. When the laws against witchcraft were repealed, the legislature continued to enable the suppression of cunning-folk and fortune-tellers. They were no longer accused of peddling Devilish if delusionary powers and leading the people astray with their blasphemous promises of magical solutions. They were now considered pestilential frauds picking the

\footnotetext{
${ }^{3}$ E.P. Evans, 'Recent Recrudescence of Superstition', Popular Science Monthly 48 (1896) $77,78$.
}

${ }^{4}$ Owen Davies, America Bewitched: The Story of Witchcraft after Salem (Oxford, 2013), pp. $56-62$. 
pockets of the credulous and 'superstitious'. The English Witchcraft and Conjuration Act of 1736 is a good example. It allowed for the prosecution of those that 'pretend to exercise or use any kind of Witcheraft, Sorcery, Inchantment, or Conjuration, or undertake to tell Fortunes'. The punishment was one year's imprisonment, quarterly stints in the pillory for one hour, and the payment of sureties for good behaviour. Laws against unlicensed medical practice were also employed to try and suppress cunning-folk, with the medical professions in France and Spain particularly active in pursuing magical healers. ${ }^{5}$

Numerous cases were heard before minor criminal courts that have not left any records, so the flourishing nineteenth-century local press, with journalists ever looking for sensational nuggets of news, often provide the only accounts of the many trials of cunningfolk and witch persecutors in the modern period. ${ }^{6}$ The national press might then pick up such local stories or those from abroad. That does not mean the newspapers exaggerated the extent of the continued belief in witchcraft. Despite the evidence to the contrary, they usually expressed their astonishment that such things could happen in the nineteenth or twentieth centuries. As with the trial records of the early-modern witch persecutions, we should always remember that cases that came to court represent only a small fraction of the witchcraft disputes that occurred in daily life across Europe.

Criminal records and newspaper reports are crucial for researching nineteenth- and twentieth-century witchcraft accusations as they enable historians to conduct record linkage. For reasons of confidentiality folklorists rarely recorded the names of the people from whom they gathered information about beliefs and customs. But prosecution records did, so we can then use censuses, parish records, maps, and other such archives to find out personal details about those involved in witchcraft disputes, how old they were, their social status, occupation, and spatial relationship to each other. A detailed study of witchcraft disputes in

\footnotetext{
${ }^{5}$ For Spain see Enrique Perdiguero, 'Magical Healing in Spain (1875-1936): Medical Pluralism and the Search for Hegemony', in de Blécourt and Davies (eds), Witchcraft Continued, pp. 133-51.

${ }^{6}$ Thomas Waters, 'Belief in Witchcraft in Oxfordshire and Warwickshire, c. 1860-1900: The Evidence of the Newspaper Archive', Midland History 34 (2009) 98-116; Tom Waters, "“They seem to have all died out": witches and witchcraft in Lark Rise to Candleford and the English countryside, c. 1830-1930' Historical Research 87 (2014) 134-153.
} 
nineteenth-century Somerset is one of the very few studies to use this approach to the subject. ${ }^{7}$

The material culture of witchcraft belief is an important if little used source of information, though more attention is now being paid to it by historians. Much of this material culture concerns the protection of buildings and their inhabitants from witcheraft and harmful intruders, and also counter-magic aimed at harming suspected witches. A lot of the surviving material, often discovered during building renovations or architectural and archaeological surveys, derives from the nineteenth century. ${ }^{8}$ Numerous so-called 'witch bottles', for example, have been found in nineteenth-century contexts in England. We know from literary sources how these were used. A bottle was filled with the urine of the bewitched, and sometimes his or her nail clippings were included. Then sharp objects such as pins, nails, and thorns were put in the bottle. The bottle was then buried or heated over a fire causing the sharp objects to get agitated. The ritual was based on the notion that there existed an imperceptible link or sympathy between witch and victim, so that the treatment of the latter's urine, whether through decay or boiling, would cause physical harm to the witch responsible. Sometimes the ritual was used to identify a witch, the excruciating pain drawing him or her to the door of the victim's house. Sometimes, particularly with the burial of bottles, it was employed to protect the home and the bewitched from an already identified witch. ${ }^{9}$ An intriguing series of Finnish finds concern frogs sealed in miniature wooden coffins and concealed under church floors. It is clear from folklore records that they operated like witch bottles and were intended to punish specific witches. ${ }^{10}$ Let us now examine what

\footnotetext{
${ }^{7}$ Owen Davies, A People Bewitched: Witchcraft and Magic in Nineteenth-Century Somerset (Bruton, 1999).

${ }^{8}$ Owen Davies, 'The Material Culture of Post-Medieval Domestic Magic in Europe: Evidence, Comparisons and Interpretations', in Dietrich Boschung and Jan Bremmer (eds), The Materiality of Magic (Paderborn, 2015), pp. 379-417.

${ }^{9}$ Brian Hoggard, 'Witch Bottles: Their Contents, Contexts and Uses', and Owen Davies and Timothy Easton, 'Cunning-Folk and the Production of Magical Artefacts' in Ronald Hutton (ed.), Physical Evidence for Ritual Acts, Sorcery and Witchcraft in Christian Britain: A
} Feeling for Magic (Basingstoke, 2015), forthcoming.

${ }^{10}$ Sonja Hukantaival, 'Frogs in Miniature Coffins from Churches in Finland Folk Magic in Christian Holy Places', Mirator 16 (2015) 192-220. 
all these sources tell us about the nature and meaning of witchcraft accusations in European societies over the last two centuries.

Decades after the laws against witchcraft were repealed people remained unaware that the authorities no longer took any interest in the popular concerns about witches. ${ }^{11}$ Into the mid-nineteenth century a few English people were still going to their local magistrate to request formal action be taken against suspected witches. The Bible was held up as supporting their extermination. Did it not say in the Old Testament, 'Thou shalt not suffer a witch to live?' The frustration with the lack of support with what seemed the self-evident criminality of witchery was expressed by a Somerset farmer named Hill who, in 1916, shot dead his neighbour for bewitching him. Hill told the arresting officer, 'I have a lot of worry here. He has bewitched my child and my pony. You don't believe in witchcraft, and the Government don't, but I do'. ${ }^{12}$

In the absence of legal support, communities occasionally took the law into their own hands. In Abergavenny, Wales, in 1827, for example, a group of men followed by a large crowd dragged a nonagenarian named Mary Nicholas for a mile to a farm where she was forced to kneel and bless a horse she was accused of bewitching. She was then stripped to the waist and thrashed with a branch of briar rose to draw her blood. The ring leaders were prosecuted for riot and common assault. At the other end of the century, in Moscow Province, Russia, in 1891, a beggar woman named Daria Vasileva was accused of witchcraft by villagers and one day two men dragged her through the street by her hair. The local policeman and several others joined them in beating her with bricks, fists, and sticks. They took her to a nearby ravine and threatened to burn her to death. She died shortly after in hospital. ${ }^{13}$ The aim of such assaults was sometimes to wring public confessions from

${ }^{11}$ On the eighteenth-century repeals see Owen Davies, 'Magic in Common and Legal Perspectives', in D.J. Collins (ed.), The Cambridge History of Magic and Witchcraft in the West: From Antiquity to the Present (Cambridge, 2015), 521-46.

${ }^{12}$ Owen Davies and Simon White, 'Witchcraft and the Somerset Idyll: The Depiction of Folk Belief in Walter Raymond's Novels', Folklore 26 (2015), 53-67.

${ }^{13}$ Davies, Witchcraft, Magic and Culture, p. 112; Christine Worobec, 'Witchcraft Beliefs and Practices in Prerevolutionary Russian and Ukrainian Villages’ Russian Review 54 (1995) 183-4. See also Christine Worobec, Possessed: Women, Witches, and Demons in Imperial Russia (DeKalb, 2003); Daniel C. Ryan, 'Witchcraft Denunciations in Late Imperial Russia: Peasant Reactions 
suspected witches or to force them to remove their spells, sometimes to bully and ostracise the accused into leaving the community permanently.

The practice of swimming witches was the most notorious expression of public justice regarding witches. In origin, swimming was a trial by water used to confirm the guilt of witches from the seventeenth century onwards. The water in a river, pool, or mill dam represented God's baptismal waters and if a suspected witch floated it was a sign of God's rejection and, therefore, a confirmation of the suspect's guilt. By the nineteenth century such swimmings were still taking place in England, the Netherlands and Germany, sometimes at the request of the person accused of witchcraft. In 1825, in the Suffolk village of Wickham Skeith, a man in his sixties named Isaac Stebbings was swum at his own asking. He was accused of bewitching a neighbour's wife. Four men were appointed to walk him into a local pond and hold him, while the local constable presided over the event to ensure it took place in an orderly fashion. Stebbings floated, and the cry went up from the gathered crowd, 'Try him again, and dip him under the water'. So he was pushed under, but continued to float. He was dragged out in a poor state. Stebbings agreed to be swum again another day with a 'control', a man his age and size to clear his reputation. This second 'scientific' swimming never took place as the local clergyman intervened. ${ }^{14}$ Just over a decade later, hundreds flocked to see the swimming of a mother of six named Christina Ceinowa, at Hela, near Danzig, West Prussia, in August 1836. It was orchestrated by eight fishermen and a cunning-man, and Christina died from the ordeal. The administrative head of the district reported the case to the Prussian government, observing that there had been similar such popular witch hunts in recent times, and noting the 'difficulties of exterminating a madness perpetuated and continued by tradition.' 15

Public lynchings also occurred very occasionally, with most reports of such community-sanction murders coming from Eastern Europe, Russia in particular. One such case was widely reported internationally in 1879. It concerned Agrafena Ignatjewa, of the

to the Koldun', Folklore: Electronic Journal of Folklore 9 (1998) 41-50; Aldona Schiffmann, 'The Witch and the Crime: The Persecution of Witches in Twentieth-Century Poland', Arv. Scandinavian Yearbook of Folklore 43 (1987) 147-65.

${ }^{14}$ Morning Chronicle, 18 July 1825.

${ }^{15}$ Nils Freytag, "Witchcraft, Witch Doctors and the Fight against "Superstition" in Nineteenth-Century Germany', in de Blécourt and Davies (eds), Witchcraft Continued, pp. 29-30. 
village of Wratschewo, Novgorod. The villagers accused her of bewitching several neighbours, trapped her in her house, nailed the windows shut, and set fire to it. Sixteen people were subsequently tried for the murder. In 1932 Reuters reported that a woman in a village in eastern Slovakia had been similarly dealt with, but had been rescued at the eleventh hour by a military patrol. ${ }^{16}$ Such collective actions against witches were very rare by the twentieth century, though. This was, in part, a consequence of increasingly sophisticated and professional policing in rural areas. We have already seen several cases in the previous century where local policeman actually participated in popular justice. There is no doubt, though, that it was increasingly unlikely for a substantive portion of a community to express solidarity with the bewitched in such a public way. Moving from a verbal accusation of witchcraft to taking physical action against the accused became an increasingly private affair.

In England it was the specific purpose of drawing blood from a witch to break his or her spell that often led to court cases. A victim from the village of Colaton Raleigh, Devon, described the experience vividly in 1860. Susannah Sullock explained to the local court: 'I was turning out my little cow in the brake, when I felt something touch me. I turned my head, and seeing the defendant [a lace-maker named Virginia Hebden], said, "How you frightened me." She answered, "You wanted to be frightened for what you ha' done to me." I said, "I have'nt a doo'd nothing to you." And she began to scratch me over my face and hands with something sharp. I was afraid she was going to kill me. She draw'd blood both on my face and hands.' 17

Scratching was not unknown elsewhere in Europe. In July 1876 a tribunal in the Loire, France, tried farmer Jean Baron, aged 37, for assault. He believed he and his livestock were bewitched. He consulted physicians but to no avail. Some reapers in his employ suggested he draw the blood of those he suspected, a man named Raynaud and his wife, and a girl named Jeannette Badieu. As they left church service one day he rushed at them and ran pins into their flesh. At his trial Baron denied having struck any blows against them, maintaining he had no intention other than to draw their blood. As he explained, 'I was ill every time I met them; and now that I have drawn some blood from them their sight produces no effect whatever on me, and I am perfectly cured; I have, therefore, reason to believe that they had cast on me an evil eye.' He happily submitted to his fifteen days' imprisonment. We hear the same expression of satisfaction in English cases. One prosecuted witch scratcher

\footnotetext{
${ }^{16}$ London Evening Standard, 11 November 1879; Gloucester Citizen, 11 January 1932.

${ }^{17}$ Taunton Courier, 18 July 1860.
} 
declared, 'I have felt better ever since I gave the scratch; it was a lucky scratch for me.' 18 With our current medical knowledge of the biochemical changes involved in creating and mitigating stress and anxiety we can better understand how the act of scratching could have had a very real cathartic impact.

In terms of one-on-one witch confrontations, in countries with widespread gun ownership we find witches being shot as well as manhandled. With the gun ownership laws for non-propertied citizens in England being restrictive, it is not surprising that the 1916 English witch-shooting mentioned earlier is the only British example. In France, where gun ownership has been more pervasive historically, witch shootings were more frequent. Amongst European Americans in nineteenth- and twentieth-century America we find numerous cases of witch shootings, and an abundance of folklore about the bewitchment of guns and advice on how to unbewitch them, particularly amongst those of German and Swiss descent. $^{19}$

As in the witch trial era, the majority of witchcraft accusations were made against women. A sample of English 'witch trials in reverse' dating from the eighteenth to the twentieth century indicated that 91 per cent of accused witches were women. An analysis of 142 such cases concerning American Europeans between 1790 and 1950 produced a similar figure of 85 per cent, with little variation over the period. In Worobec's survey of seventyfive witchcraft accusations, mostly from the late nineteenth and early twentieth-century, over 70 per cent were women, and de Blécourt's survey of newspapers in the western Netherlands, for roughly the same period, revealed 94 per cent were women. ${ }^{20}$ Much more research is required to examine whether the same social, cultural, economic, and theological reasons were at play in the modern period as the early modern to generate this preponderance of female accused. We certainly find similar issues, environments, and situations regarding the origin of accusations in both periods. In Worobec's survey, for example, twelve per cent of the accused were poverty-stricken women, some of whom went begging, an activity that was at the heart of a number of accusations. This echoes numerous cases from the modern and

\footnotetext{
${ }^{18}$ Edinburgh Evening News, 25 July 1876; Davies, People Bewitched, p. 125.

${ }^{19}$ Davies, America Bewitched, pp. 42-44.

${ }^{20}$ Davies, Witchcraft, p. 193; Davies, America Bewitched, p. 68; Worobec, 'Witchcraft

Beliefs and Practices', 168; Willem de Blécourt, 'Boiling Chickens and Burning Cats:

Witchcraft in the Western Netherlands, 1850-1925', in de Blécourt and Davies (eds),

Witchcraft Continued, p. 94.
} 
early-modern archives of accused female witches, often marginal and elderly, who went begging, were refused charity, and subsequently faced witchcraft accusations when misfortune struck the uncharitable householders. In terms of differences between the content of accusations in the two periods, the Devil and diabolic elements such as sabbaths, diabolic sexual relations, and familiars, are certainly less present in nineteenth- and twentieth-century witchcraft accusations. This is understandable as the prominence of such accounts in witchtrial records is principally due to the use of torture (on the continent) and the leading questions devised by the investigating authorities to confirm the existence of the satanic conspiracies that most concerned them - rather than the simple acts of maleficium that preoccupied most common people.

The small number of witch accusations against men usually occurred in working environments where women were largely absent, such as dealing with horses and fishing, or derived from personal rivalries. The latter would seem to lie behind a defamation suit heard in November 1893, which concerned an accusation of witchcraft made by a miner and innkeeper named Timmel against a shoemaker named Liebscher from the village of Müdisdorf, Freiburg. Timmel's chickens and cows were unproductive while Liebscher's were prolific. It was clear to Timmel that the shoemaker had a cast a spell upon his animals, thereby transferring their productivity to his. ${ }^{21}$ Men made up the majority of cunning-folk, and some male accused witches were cunning-men. Such accusations sometimes occurred when clients consulted them about their suspected bewitchment and paid for treatment but then got worse rather than better. The suspicion then arose that certain people, the suspected witches perhaps, had employed the cunning-folk to double bewitch them. Or maybe the cunning-folk were trying to extract more money for ongoing treatment.

Digging deeper into the profile of the accused, the aforementioned nineteenth-century Somerset study of twenty-six 'witch trials in reverse' found that most of the accused were aged between fifty and seventy. Journalistic descriptions of the accused confirm that few conformed to the stereotypical 'hag-like' witch of folk tales. In other words, few accusations were made because someone looked like a witch. A third of them were widows and two were spinsters, suggesting that issues of female independence, marginality, and lack of patriarchal control, may have been a significant factor.

As we have seen, those accused of witchcraft had the law on their side in terms of punishing their accusers. But going to court was stressful and time consuming. In terms of

\footnotetext{
${ }^{21}$ Evans, 'Recent Recrudescence', 79.
} 
slander, the accused occasionally preferred the medium of the press to broadcast their innocence and shame their accusers. When, in 1892, Victoria Seifritz was accused of bewitching the stables of the burgomaster of Schapbach, Baden, Germany, thereby causing an epidemic of hoof disease, she decided not to launch a slander suit but to take out a notice in the local newspaper stating categorically that she was not a witch. ${ }^{22}$ In 1910 Mary Jane Dance decided to deal with the gossip about her in the Worcestershire village of Eckington by placing the following advertisement in the local newspaper:

Whereas a certain Mary Jane Dance, wife of John Dance, of the village named, has been repeatedly slandered in common talk and gossip as a witch, together with other false and injurious accusations against her character, whereby she has suffered grievously in mind and body in the esteem and fellowship of her neighbours, any repetition of these offences will result in action being taken against the slanderer. ${ }^{23}$

Cunning-folk were involved at some stage in many accounts of witchcraft disputes in the period. They were employed to diagnose witchcraft, identify witches, and provide the charms and spells that could cure and prevent bewitchment. They were usually careful about naming specific people as witches, though. A common technique was to confirm the suspicions of their clients. There are numerous account of the tricks they played to get such information. This sometimes involved the use of stooges who sat in the waiting rooms of cunning-folk and engaged clients in conversation. The deathbed confession of a Lancashire cunning-man named Old Robinson illustrates the ruse well:

There was a large field sloping from the house. When a person was seen coming up this field, Robinson went into a back room, where he could hear what was said in the front room. His wife asked the person to sit down, saying her husband would be in soon, and she then questioned the person about his errand. When Robinson thought he had heard sufficient, he went out at the back door, took a circuit, and came up the field; and when he came in and seemed to know everything about the matter the person was astonished. ${ }^{24}$

\footnotetext{
22 Evans, 'Recent Recrudescence', 78.

${ }^{23}$ Nottingham Evening Post, 20 June 1910.

${ }^{24}$ Owen Davies, 'Cunning-Folk in England and Wales during the Eighteenth and Nineteenth Centuries', Rural History 8 (1997) 99.
} 
A less devious operation was to ask the client to look into some reflective surface, perform some spell, and ask the client who they saw. Sometimes the rituals they employed for identifying witches, or advised clients to carry out, led to people with absolutely no reputation for magic, harmful or otherwise, being accused and abused; they merely came calling at the wrong moment during a ritual, such as the boiling of a witch bottle. These accidental witches could be, up until this moment, long-standing friends of or good neighbours with the bewitched.

With compulsory education widespread, there was an assumption by the end of the nineteenth century that only the elderly continued to fear the power of witches. But this was not the case. The Somerset study shows that the majority of those scratching accused witches were aged between twenty and forty. All eight male defendants were in this age group, demolishing the contemporary view that women as well as the elderly were inherently more 'superstitious' with regard to witchcraft. As to social status, most of the accused and accusers in the Somerset reverse trials were from the labouring classes. It is absolutely clear from the wider sources, though, that in Somerset, nationally, and across Europe, witchcraft accusations were made by a wider social group. As is already indicated by some of the cases mentioned earlier, farmers made up a substantial group of accusers, as well as crafts and tradespeople. It may be that the higher up the social scale the more likely that witchcraft disputes were dealt with remotely using counter-magic - in other words without directly confronting the accused, due to personal concerns over how such an assault might harm their reputations amongst their peer groups. Witchcraft accusations were not exclusive to rural areas, either. Our knowledge of witchcraft in urban areas is severely impeded by the fact that nineteenth- and earlytwentieth-century folklorists largely avoided towns and cities assuming that urban industrial areas, as supposed beacons of modernity, were naturally void of 'superstitious' beliefs and practices. ${ }^{25}$ But numerous disputes played out in small and large urban areas of Europe in the period. In March, 1893, for example, a bus driver in the town of Yeovil, Somerset, named Frederick Terrell, aged thirty-one, stood before the door of Harriett Carew, and yelled that she was an 'old witch' who bewitched his sister, and threatened to beat her brains out. ${ }^{26}$

\footnotetext{
${ }^{25}$ See, for example, Owen Davies, 'Urbanization and the Decline of Witchcraft: An Examination of London', Journal of Social History 30 (1997), 597-617. On magic and urban culture in England in the period see Karl Bell, The Magical Imagination: Magic and
} Modernity in Urban England, 1780-1914 (Cambridge, 2012).

${ }^{26}$ Davies, People Bewitched, pp. 151-2. 
There is no doubt that in Europe public witchcraft accusations were uncommon events by the mid-twentieth-century. But they continued to occur often enough to be significant for historical and ethnographic study. In post-Second World War Germany there was considerable concern about the continued belief in witchcraft and the resort to cunning-folk and magic books. In the 1950s the German Medical Information Service estimated that there were around seventy civil and criminal law suits a year concerning accusations of witchcraft. ${ }^{27}$ From the 1920 s through to the 1950 s a former German schoolteacher named Johann Kruse, whose own mother had been slandered as a witch, attracted the interest of the international press for his campaign against the social and personal harm that the continued belief in witchcraft was causing. There was no such formal campaigning in neighbouring France at the time, but the courts continued to deal periodically with the results of witchcraft disputes, with sporadic shootings of accused witches occurring into the $1980 \mathrm{~s} .{ }^{28}$ More research in other parts of Europe might reveal similar levels of legal involvement in witchcraft disputes. That said, assaults and court cases were very rare in England after the 1910s. But as the ethnographic studies of witchcraft in France and Germany show, witcheraft disputes continued to play out in dramatic fashion in private and often unspoken ways without ending in public accusations.

\footnotetext{
${ }^{27}$ Monica Black, "Miracles in the Shadow of the Economic Miracle: The "Supernatural 50s" in West Germany', Journal of Modern History 84 (2012) 846. More generally see Joachim Friedrich Baumhauer, Johann Kruse und der “neuzeitliche Hexenwahn”: Zur Situation eines norddeutschen Aufklärers und einer Glaubensvorstellung im 20. Jahrhundert (Neumünster, 1984).

${ }^{28}$ Owen Davies, 'Witchcraft accusations in France 1850-1990' in de Blécourt and Davies (eds), Witchcraft Continued, pp. 107-132.
} 